\title{
PENGARUH CAMPURAN BAHAN BAKAR PERTALITE-BIOETANOL BIJI SORGHUM PADA MESIN BENSIN
}

\section{EFFECT OF SORGHUM SEEDS PERTALITE-BIOETHANOL BLEND FUEL IN GASOLINE ENGINE}

\author{
*Abdi H. Sebayang, H. Ibrahim, S. Dharma, A.S. Silitonga, dan B. Ginting \\ Jurusan Teknik Mesin, Politeknik Negeri Medan
}

\author{
N. Damanik \\ PT PLN (Persero) PUSLITBANG
}

Submitted: 04-11-2018; Revised: 22-07-2019; Accepted: 22-07-2019

\begin{abstract}
The depletion of fossil fuels, rising of earth temperatures and declining air quality is an unavoidable phenomenon today. This condition is a result of increased and excessive use of fossil fuels. Bioethanol fuel is one solution to reduce this problem that is sourced from renewable raw materials. Sorghum seeds are raw materials that have the potential to be made bioethanol due to a high carbohydrate content (70\%). The test has performed the use of pertalite-bioethanol blends fuels was on a four-stroke gasoline engine without modification. The percentage of the mixture volume of fuel used is 10\% bioethanol-90\% pertalite (E10), 15\% bioethanol-85\% pertalite (E15) and $20 \%$ bioethanol-80\% pertalite (E20). Engine speeds vary from 1000 to $4000 \mathrm{rpm}$, and properties of the sorghum seeds bioethanol-pertalite blends are measured and analyzed. The purpose of this study is to investigate engine performance and exhaust emissions at the gasoline engine by using the sorghum seeds bioethanol-pertalite blends with different mixed ratios (E10, E15, and E20). Engine performance includes engine torque, brake specific fuel consumption (BSFC) and thermal brake efficiency (BTE) was analyzed. Besides, carbon monoxide (CO), hydrocarbon (HC), and nitrogen oxide (NOx) emissions are measured as gasoline engine exhaust emissions. The results show that BSFC decreased while BTE increased for a fuel blends containing $20 \%$ bioethanol at $3500 \mathrm{rpm}$ engine speed, with each maximum value of $246.93 \mathrm{~g} / \mathrm{kWh}$ and $36.28 \%$. It is also found that CO and HC emissions are lower for the sorghum seeds bioethanol-pertalite blends. Based on the research results, it can be concluded that the sorghum seeds bioethanol-pertalite blends can improve engine performance and reduce exhaust gas emissions.
\end{abstract}

Keywords: Alternative Fuel; Bioethanol; Exhaust Gas Emission; Performance Engine; Pertalite.

\begin{abstract}
ABSTRAK
Menipisnya bahan bakar fosil, meningkatnya suhu bumi dan memburuknya kualitas udara merupakan fenomena yang tak terelakan pada saat sekarang ini. Kondisi ini merupakan akibat dari pemakaian bahan bakar fosil yang meningkat dan berlebihan. Bioetanol, bahan bakar yang bersumber dari bahan baku terbarukan, merupakan salah satu solusi untuk mengurangi masalah ini. Biji Sorghum
\end{abstract}

*Corresponding author: abdisebayang@yahoo.co.id

Copyright @ 2020 THE AUTHOR(S).This article is distributed under a Creative Commons Attribution-Share Alike 4.0 International license. Jurnal Teknosains is published by the Graduate School of Universitas Gadjah Mada. 
adalah bahan baku yang berpotensi untuk dijadikan bioetanol karena memiliki kandungan karbohidrat yang tinggi (70\%). Pengujian bahan bakar campuran pertalite-bioetanol dilakukan pada mesin bensin empat langkah tanpa modifikasi. Persentase volume campuran bahan bakar yang digunakan adalah 10\% bioetanol- $90 \%$ pertalite (E10), 15\% bioetanol-85\% pertalite (E15) dan $20 \%$ bioetanol- $80 \%$ pertalite (E20). Putaran mesin bervariasi dari 1000 hingga $4000 \mathrm{rpm}$, dan sifat-sifat dari campuran pertalite-bioetanol biji Sorghum diukur dan dianalisis. Tujuan dari penelitian ini adalah untuk menyelidiki kinerja mesin dan emisi gas buang mesin bensin dengan menggunakan bahan bakar campuran pertalite-bioetanol biji Sorghum (E10, E15 dan E20). Kinerja mesin berupa torsi mesin, konsumsi bahan bakar spesifik rem (BSFC) dan efisiensi termal rem (BTE) dianalisis. Selain itu, emisi karbon monoksida (CO), hidrokarbon (HC), dan nitrogen oksida (NOx) diukur sebagai emisi gas buang mesin bensin. Hasil penelitian menunjukkan bahwa BSFC menurun sementara BTE meningkat pada campuran bahan bakar yang mengandung 20\% bioetanol (E20) pada putaran mesin $3500 \mathrm{rpm}$, dengan masing-masing nilai maksimum 246,93 g/ kWh dan 36,28\%. Juga ditemukan bahwa emisi $\mathrm{CO}$ dan $\mathrm{HC}$ lebih rendah untuk campuran pertalite-bioetanol biji Sorghum. Berdasarkan hasil penelitian, dapat disimpulkan bahwa bahan bakar campuran pertalite-bioetanol biji Sorghum dapat meningkatkan kinerja mesin dan mengurangi emisi gas buang.

Kata Kunci: Bahan Bakar Alternatif; Bioetanol; Emisi Gas Buang; Kinerja Mesin; Pertalite.

\section{PENGANTAR}

Menurunnya kualitas udara, menipisnya cadangan minyak bumi, dan dampak pemanasan global merupakan akibat penggunaan bahan bakar fosil yang semangkin meningkat maka diperlukan suatu energi alternatif pengganti bahan bakar fosil yang ramah terhadap lingkungan. Bioetanol merupakan salah satu bahan bakar alternatif yang paling menguntungkan untuk dicampur dengan bensin dan digunakan pada mesin pembakaran dalam (Sebayang dkk., 2017b). Dalam hal penggunaan, penyimpanan dan pengangkutan bahan bakar bioetan etanol mirip dengan bahan bakar bensin (Çay dkk., 2013). Selain itu, bioetanol dapat diproduksi dari bahan baku nonpangan yaitu biji Sorghum yang merupakan biofuel generasi kedua (Aditiya $d k k ., 2016$ ).

Ada beberapa kelebihan Sorghum dibanding dengan tanaman pangan lainnya seperti memiliki produksi biji dan biomasa yang tinggi, memiliki sifat tahan terhadap kekeringan dan kebutuhan air lebih sedikit (Marx dkk., 2014; Mehboob dkk., 2015; Zhang $d k k ., 2010)$. Sementara itu, kandungan pati yang dimiliki biji Sorghum juga cukup tinggi berkisar $73 \%$ sehingga dapat dihidrolisis menjadi gula sederhana (Sebayang $d k k .$, 2017a). Di sisi lain, sebagai sumber energi terbarukan yang diperoleh dari biomassa, bioetanol merupakan bahan bakar alternatif untuk bensin tanpa timbal sebagai bahan bakar otomotif, dan dapat digunakan tanpa modifikasi mesin (Sebayang $d k k$., 2016). Implementasi bioetanol di mesin penyalaan dengan menggunakan busi telah diteliti dan dinilai dengan parameter kinerja mesin seperti, efisiensi termal rem (brake thermal efficiency, BTE), konsumsi bahan bakar spesifik rem (brake specific fuel consumption, BSFC), daya rem (brake power, BP) dan juga emisi gas buang.

Banyak tulisan telah dilakukan untuk mengurangi emisi dan memperbaiki kinerja mesin. Sebagai pengganti bahan bakar bensin, campuran bioetanol-bensin dapat memperbaiki kinerja mesin dan mengurangi emisi gas buang. Najafi dkk. (2009) menyelidiki kinerja mesin penyalaan dengan menggunakan busi empat langkah dengan bahan bakar campuran bensin-etanol dan mereka mengamati bahwa E20 meningkatkan efisiensi pembakaran 35\%. Sedangkan untuk konsumsi bahan bakar spesifik mengalami penurunan dibanding penggunaan bahan bakar bensin. Demikian pula (Koç dkk., 2009) menggunakan rasio etanol yang lebih tinggi pada campuran (E50 dan E85) pada mesin penyalaan dengan menggunakan busi satu silinder. Mereka menyatakan bahwa konsumsi bahan bakar spesifik rem (BSFC) meningkat masing-masing $20,3 \%$ dan $45,6 \%$ untuk E50 dan E85.

Selain itu, emisi gas buang dianalisis oleh Ghazikhani $d k k$. (2013), mesin penyalaan dengan menggunakan busi dua langkah menggunakan bahan bakar campuran bensin-etanol. Mereka 
ABDI H. SEBAYANG, H. IBRAHIM, S. DHARMA, A.S. SILITONGA, B. GINTING, DAN

N. DAMANIK \& PENGARUH CAMPURAN BAHAN BAKAR PERTALITE-BIOETANOL BIJI ...

menyimpulkan bahwa pengurangan emisi karbon monoksoda (CO) dan nitrogen oksida (NOx) sebesar 32\% dan 38\% dengan menggunakan campuran bahan bakar bensinetanol pada konsentrasi 15\%. Sementara itu, Schifter dkk. (2011) mengamati bahwa 20\% campuran etanol dalam mesin silinder tunggal menyebabkan emisi CO dan hidrokarbon $(\mathrm{HC})$ berkurang masing-masing $52 \%$ dan $19 \%$.

Dari uraian di atas, penggunaan campuran bahan bakar bensin-etanol mendapatkan hasil yang baik. Untuk itu, diperlukan suatu bahan bakar alternatif terbarukan yaitu bioetanol yang kemudian dicampurkan dengan pertalite sehingga dapat mengurangi emisi gas buang pada mesin penyalaan dengan menggunakan busi empat langkah dua silinder. Penelitian ini menggunakan biji Sorghum sebagai bahan baku untuk produksi bioetanol karena shorgum merupakan salah satu bahan baku yang tidak dapat dimakan (non-pangan). Penggunaan bahan baku nonpangan sebagai bahan dasar produksi bioetanol sangat penting karena tidak bersaing dengan kebutuhan pangan (Ibrahim dkk., 2017).

Sorghum merupakan salah satu tanaman yang berasal dari wilayah sekitar Afrika, tetapi sekarang ini tanaman Sorghum telah menyebar ke wilayah Asia (Elhassan $d k k$., 2015; Mehboob $d k k$., 2015). Sorghum (Sorghum bicolor (L) Moench) adalah tanaman yang mempunyai adaptasi luas karena dapat tumbuh mulai dari daerah dataran rendah sampai dataran tinggi dengan iklim tropis kering sampai daerah iklim basah (Deesuth $d k k$., 2015). Kemudian Sorghum juga dapat tumbuh pada lahan marginal utamanya lahan kering dimana tanaman lain tidak dapat tumbuh (Elhassan $d k k ., 2015$; Marx $\left.d k k_{.}, 2014\right)$. Sementara itu, Sorghum juga memiliki waktu regenerasi yang singkat di antara 3-5 bulan, kebutuhan pupuk yang rendah dan laju fotosintesis tanaman Sorghum lebih cepat dibandingkan dengan tebu dan jagung (Deesuth $d k k$., 2015; Houx III dan Fritschi, 2015). Selain itu, Sorghum juga merupakan bahan baku yang sangat baik untuk produksi biofuel karena Sorghum memiliki fraksi yang berbeda seperti, pati (biji-bijian), jus (stem), ampas tebu (batang), dan daun (Pengilly $d k k ., 2015)$.

\section{METODE}

\section{Persiapan Bahan Baku Biji Sorghum}

Sorghum (Sorghum bicolor (L.) Moench) dibeli dari Kroya, kabupaten Cilacap, Jawa Tengah. Sebelum digunakan, biji Sorghum pertama sekali dicuci dan kemudian dikeringkan untuk mempermudah pengupasan kulitnya. Setelah ini, biji Sorghum ditumbuk dan disaring untuk mendapatkan pati. Hasil penumbukan biji Sorghum berbentuk tepung dan memiliki ukuran yang lebih kecil dari satu milimeter (125$150 \mu \mathrm{m})$ dan hal ini akan memiliki pengaruh penguraian pati menjadi glukosa pada proses hidrolisis. Ukuran partikel yang lebih kecil akan mengurangi efek pembatasan difusi dan mengakibatkan hasil gula yang lebih tinggi dibandingkan dengan ukuran partikel yang lebih besar (Barcelos dkk., 2011). Untuk waktu penyimpanan yang lebih lama, biji Sorghum dikeringkan, dan disimpan pada suhu $25^{\circ} \mathrm{C}$.

\section{Komposisi Biji Sorghum}

Pati biji Sorghum disimpan dalam wadah tertutup di lemari pendingin sebelum percobaan dilakukan. Pati biji Sorghum terdiri dari partikel dengan diameter 125-150 $\mu \mathrm{m}$ (98\% atau lebih partikel melewati saringan $150 \mu \mathrm{m})$. Menurut Sebayang $d k k$. (2017a) komponen utama pati biji Sorghum terdiri dari beberapa komponen seperti yang diperlihatkan pada tabel 1.

Table 1

Komponen Pati Biji Sorghum

\begin{tabular}{l|l|l}
\multicolumn{1}{c|}{ Komponen } & \multicolumn{1}{c|}{ Unit } & Kandungan \\
\hline Karbohidrat & \%wt. & 73,10 \\
\hline Protein & \%wt. & 10,30 \\
\hline Lemak & \%wt. & 3,15 \\
\hline Abu & $\% w t$. & 1,56 \\
\hline Serat & $\% w t$. & 1,70 \\
\hline Konten kelembapan & \%wt & 10,20 \\
\hline
\end{tabular}

Sumber: Sebayang $d k k$. (2017a)

Dapat dilihat dari tabel di atas bahwa lebih besar $70 \%$ pati Sorghum terdiri dari karbohidrat dan hal ini menjadikan pati biji Sorghum mempunyai potensi untuk menjadi bahan bakar bioetanol. 


\section{Katalis (reagen)}

Katalis atau reagen yang digunakan untuk produksi bioetanol dalam penelitian ini adalah asam 3,5-dinitrosalisilat (DNS), kalium dihidrogen fosfat $\left(\mathrm{KH}_{2} \mathrm{PO} 4\right)$, amonium klorida $\left(\mathrm{NH}_{4} \mathrm{Cl}\right)$, pelet natrium hidroksida $(\mathrm{NaOH}$, dengan kemurnian 99,9\%), natrium kalium tartrat, enzim a-amilase dari Bacillus licheniformis Tipe XII-A, enzim amil_oglukosidase dari Aspergillus niger, ragi dari Saccharomyces cerevisiae, ekstrak ragi, pepton bakteri, D-glukosa, dan potato dextrose. Semua katalis ini dibeli dari SigmaAldrich dan digunakan tanpa pemurnian.

\section{Persiapan Mikroorganisme}

Ragi Saccharomyces cerevisiae Tipe II, yang dibeli dari Sigma-Aldrich digunakan untuk memfermentasi pati biji Sorghum menjadi bioethanol. Ragi Saccharomyces cerevisiae Tipe II kering instan diaktifkan dengan menambahkan $100 \mathrm{~mL}$ air suling steril ke dalam $150 \mathrm{~mL}$ labu. Ragi pepton dekstrosa (yeast peptone dextrose, YPD) dibuat dengan dua gram ekstrak ragi, empat gram pepton bakteri, empat gram glukosa dan 12 gram agar dalam $200 \mathrm{~mL}$ air suling. Ragi kemudian diinokulasi dalam agar ragi pepton dekstrosa dalam cawan kaca atau petri dish (Widianto $d k k ., 2013$ ). Setelah itu, ragi disimpan dalam inkubator pada suhu $37^{\circ} \mathrm{C}$ selama 24 jam sebelum digunakan untuk produksi bioetanol. Enzim a-amilase dari Bacillus licheniformis Tipe XII-A dan enzim amiloglukosidase dari Aspergillus niger digunakan sebagai katalis untuk likiufikasi dan sakarifikasi. Aktivitas enzimatik untuk a-amilase dan amiloglukosidase ditentukan masing-masing $\geq 500 \mathrm{U} /$ gram protein dan $300 \mathrm{U} / \mathrm{mL}$.

\section{Analisis Gula Reduksi (reducing sugar)}

Konsentrasi kadar gula ditentukan dengan menggunakan metode DNS (Miller, 1959). Pertama, satu mililiter larutan gula reduksi diencerkan dengan air suling dalam tabung reaksi. Selanjutnya, satu mililiter larutan DNS ditambahkan ke larutan gula reduksi dan campuran kemudian dipanaskan pada suhu 90 ${ }^{\circ} \mathrm{C}$ selama lima menit. Selanjutnya, campuran didinginkan dan diencerkan, dan absorbansi diukur menggunakan ultraviolet-visible spectro- photometer (SPEKOL $®$ 1500, Analytik Jena, Berlin, Germany).

\section{Proses Hidrolisis}

Proses hidrolisis enzimatik dilakukan dengan menyiapkan pati biji Sorghum 24\% (b/v) dalam labu diisi dengan air suling. Proses likiufikasi dilakukan menggunakan $0,1 \%$ (v/v) a-amilase dari Bacillus licheniformis tipe XII-A (500 U/mg) pada suhu $90{ }^{\circ} \mathrm{C}$ dan kecepatan langkah $75 \mathrm{spm}$. Selanjutnya, 0,1\% (v/v) amiloglukosidase dari Aspergillus niger $(300 \mathrm{U} / \mathrm{mL})$ ditambahkan ke dalam campuran dan proses sakarifikasi dilakukan pada $70{ }^{\circ} \mathrm{C}$ selama 240 menit. Selama lima menit, sempel disentrifugasi pada $10.000 \mathrm{rpm}$ untuk memisahkan residu padat. Metode DNS digunakan untuk mengukur jumlah gula reduksi untuk setiap hidrolisat.

\section{Proses Fermentasi}

Prosesfermentasidilakukan menggunakan labu Erlenmeyer 2-L. Setiap labu Erlenmeyer diisi dengan pati biji Sorghum yang sudah dihidrolisa dan campuran nutrisi fermentasi sebagai berikut: 10 gram ekstrak ragi, empat gram kalium dihidrogen fosfat $\left(\mathrm{KH}_{2} \mathrm{PO} 4\right)$, dan dua gram amonium klorida $\left(\mathrm{NH}_{4} \mathrm{Cl}\right)$ untuk setiap $1.000 \mathrm{~mL}$ hidrolisat. Larutan dicampur dan kemudian disterilkan pada suhu 125 ${ }^{\circ} \mathrm{C}$ dalam autoklaf selama 35 menit. Larutan steril diinokulasi dengan ragi Saccharomyces cerevisiae. Akhirnya, labu ditempatkan dalam pengocok inkubator dan diatur pada suhu dan kecepatan agitasi masing-masing $37^{\circ} \mathrm{C}$ dan 120 rpm, untuk proses fermentasi selama 84 jam.

\section{Proses Penyulingan}

Penyulingan dilakukan menggunakan alat penguap yang berputar pada suhu, tekanan, dan kecepatan putar masing-masing $60^{\circ} \mathrm{C}, 175$ mbar, dan $100 \mathrm{rpm}$. Larutan fermentasi yang diuapkan diisap oleh pompa dan dialirkan ke ujung lainnya untuk dikondensasi dan menghasilkan peningkatan kualitas larutan bioetanol.

\section{Analisis Bioetanol Biji Sorghum}

Konsentrasi bioetanol diukur menggunakan sistem gas kromatografi (Agilent 
ABDI H. SEBAYANG, H. IBRAHIM, S. DHARMA, A.S. SILITONGA, B. GINTING, DAN

N. DAMANIK \& PENGARUH CAMPURAN BAHAN BAKAR PERTALITE-BIOETANOL BIJI ...

7890A, Agilent, Santa Clara, USA) yang memiliki detektor konduktivitas termal dan kolom DB-ALC2 (Agilent, Santa Clara, dan USA) yang memiliki dimensi $30 \mathrm{~m} \times 0,32 \mathrm{~mm}$. Helium digunakan sebagai gas pembawa, dengan laju aliran 1,5 mL/menit. Suhu injektor dan detektor masing-masing adalah 150 dan $200^{\circ} \mathrm{C}$. Spektroskopi Fourier transform infrared (FTIR) (Bruker Tensor 27, Bruker, Billerica, MA, dan USA) dilakukan untuk menentukan struktur kimia dari bioetanol biji Sorghum. Bioetanol biji Sorghum dianalisis dengan menggunakan kompartemen sampel refleksi total yang dilemahkan dalam wilayah pertengahan inframerah dalam kisaran bilangan gelombang $4.000-400 \mathrm{~cm}^{-1}$.

\section{Prosedur Pengujian dan Desain Eksperimental}

Penelitian unjuk kerja mesin dilakukan pada mesin bensin, dua silinder, dan empat langkah. Dinamometer digabungkan dengan sistem mesin dan unit pengontrol. Spesifikasi mesin diberikan pada tabel 2. Selain itu, emisi gas buang dianalisis menggunakan BOSCH BEA 350 seperti karbon monoksida, hidrokarbon, dan nitrogen oksida. Rentang pengukuran dan keakuratan instrumen yang digunakan diberikan dalam tabel 3. Sementara itu, skema tata letak dari pengaturan eksperimental ditunjukkan pada Gambar 1.

Tabel 2

Spesifikasi Mesin Pengujian

\begin{tabular}{l|l}
\hline \multicolumn{1}{c|}{ Parameter Mesin } & \multicolumn{1}{|c}{ Nilai } \\
\hline Nama Mesin & Daihatsu \\
\hline Tipe Mesin & Siklus 4-langkah \\
\hline Jumlah Silinder & 2 Silinder \\
\hline Bore x Stroke & $71,66 \mathrm{~mm}$ x $68 \mathrm{~mm}$ \\
\hline Isi Silinder & $550 \mathrm{cc}$ \\
\hline Sistem Pembakaran & Firing Order \\
\hline Torsi Maksimum & 4,2 kg.m $(41 \mathrm{~N} . \mathrm{m}) / 4000 \mathrm{rpm}$ \\
\hline Tenaga Maksimum & 30 PS $(22 \mathrm{~kW}) / 5500 \mathrm{rpm}$ \\
\hline Kapasitas oli & 2 Liter \\
\hline Sumber: Analisis Data (2018)
\end{tabular}

Tabel 3

Spesifikasi Alat Analisis Gas Buang

\begin{tabular}{l|l|l}
\hline $\begin{array}{c}\text { Komponen } \\
\text { emisi }\end{array}$ & \multicolumn{1}{c|}{$\begin{array}{c}\text { Rentang } \\
\text { pengukuran }\end{array}$} & \multicolumn{1}{|c}{ Resolusi } \\
\hline $\begin{array}{l}\text { Karbon } \\
\text { monoksida }\end{array}$ & $0-10 \% \mathrm{vol}$ & $0,001 \% \mathrm{vol}$ \\
\hline Hidrokarbon & $0-9999 \mathrm{ppm}$ vol & $1 \mathrm{ppm} \mathrm{vol}$ \\
\hline $\begin{array}{l}\text { Nitrogen } \\
\text { oksida }\end{array}$ & $0-5000 \mathrm{ppm}$ vol & $\leq 1 \mathrm{ppm}$ vol \\
\hline
\end{tabular}

Sumber: Analisis Data (2018)

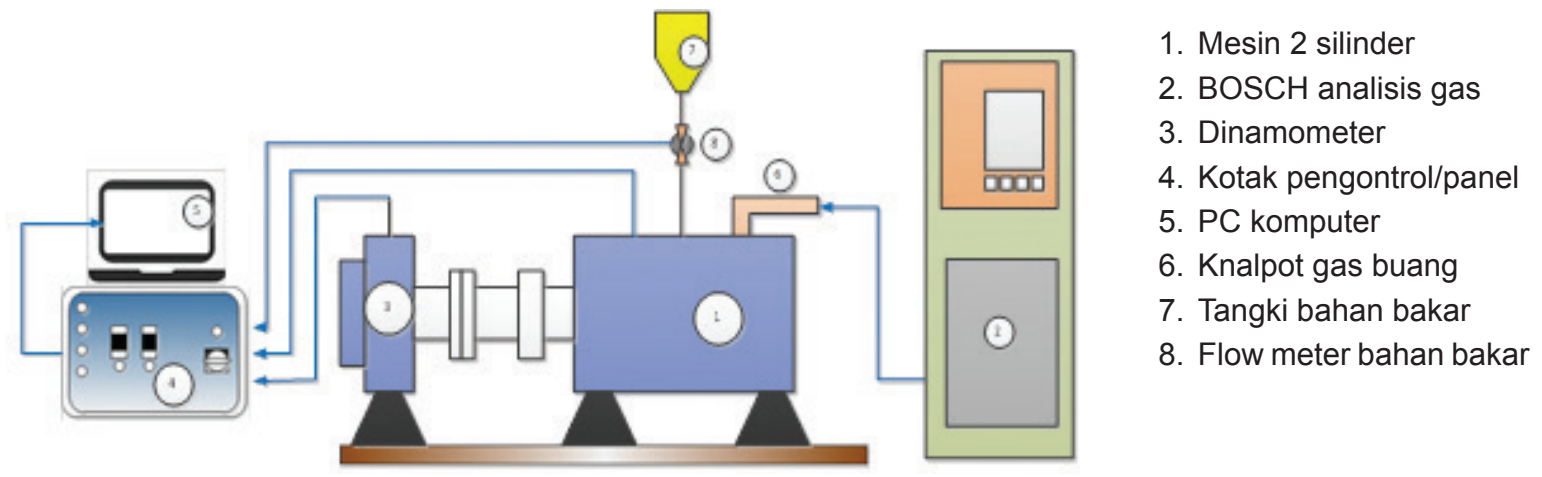

Gambar 1. Diagram Skematis dari Mesin Bensin Percobaan Sumber: Analisis Data (2018)

Perhitungan Parameter Kinerja Mesin

BSFC dan BTE dihitung sesuai dengan konsumsi bahan bakar dan tenaga rem dalam kajian ini. BSFC adalah parameter yang sangat berguna dari kinerja mesin karena menunjukkan jumlah bahan bakar yang dibutuhkan untuk menghasilkan daya keluaran mesin tertentu. BSFC dan BTE ditentukan menggunakan masing-masing dengan persamaan 1 dan 2 (Teoh $d k k ., 2015)$. 
BSFC $=\frac{\text { Konsumsi Bahan Bakar }}{\text { Daya keluar }}$

BTE $=\frac{\text { Daya rem x } 3600}{\text { LHV x Konsumsi Bahan Bakar }}$

\section{Sifat Campuran Bahan Bakar Pertalite-Bioetanol Biji Sorghum}

Sifat-sifat bioetanol biji Sorghum dan dicampur dengan pertalite $(10 \%, 15 \%$ dan $20 \%$ yang disebut E10, E15, dan E20) dievaluasi dan dibandingkan dengan bahan bakar pertalite.
Pertalite digunakan dalam penelitian ini sebagai bahan bakar dasar dan dibeli dari Pertamina. Pertalite memiliki angka oktan 90. Selain itu, sifat-sifat pertalite dan campuran pertalitebioetanol biji Sorghum diperiksa berdasarkan standar ASTM dan membandingkannya dengan penelitian lain yang dapat dilihat pada tabel 4. Campuran pertalite-bioetanol disiapkan sebelum memulai percobaan untuk memastikan bahwa campuran bahan bakar adalah homogen untuk menghindari reaksi bioetanol dengan air.

Tabel 4

Sifat-Sifat Fisika Kimia Pertalite Dan Campuran Pertalite-Bioetanol Biji Sorghum

\begin{tabular}{l|l|l|l|l|l|l|l|l}
\hline \multicolumn{1}{c|}{ Sifat-sifat } & Pertalite & $\begin{array}{c}\text { Bioetanol } \\
\text { biji } \\
\text { Sorghum }\end{array}$ & \multicolumn{1}{|c|}{ E10 } & \multicolumn{1}{|c|}{ E15 } & E20 & $\begin{array}{c}\text { E20 (Yücesu } \\
\text { dkk., 2006) }\end{array}$ & $\begin{array}{c}\text { E20 (Masum } \\
\text { dkk., 2015) }\end{array}$ & Metode \\
\hline $\begin{array}{l}\text { Kandungan } \\
\text { oksigen (\% wt) }\end{array}$ & 0 & 35,6 & 4,89 & 6,69 & 6,98 & - & 7,36 & ASTM D 4814 \\
\hline $\begin{array}{l}\text { Densitas }\left(20^{\circ} \mathrm{C}\right) \\
\left(\mathrm{kg} / \mathrm{m}^{3}\right)\end{array}$ & 770 & 807 & 774,1 & 775,7 & 777,6 & 771,5 & 759,7 & ASTM D 4052 \\
\hline $\begin{array}{l}\text { Nilai kalor }(\mathrm{MJ} / \\
\mathrm{kg})\end{array}$ & 44,14 & 27,298 & 41,51 & 40,86 & 40,19 & 40,430 & 39,47 & ASTM D 240 \\
\hline Nilai oktan & 90 & 108 & 91,8 & 92,7 & 93,6 & 89,81 & 93 & ASTM D 2699 \\
\hline
\end{tabular}

Sumber: Analisis Data (2018)

Semua campuran pertalite-bioetanol biji Sorghum diuji di bawah kondisi putaran mesin yang berbeda. Sebelum melakukan percobaan, pencampuran bahan bakar dipastikan bahwa campuran bahan bakar bioetanol biji Sorghum dengan pertalite homogen. Kinerja dan emisi gasa buang dari mesin diteliti pada bahan bakar bioetanol biji Sorghum dicampur dengan Pertalite (E10, E15, dan E20) dengan variasi putaran mesin dan kemudian dibandingkan dengan kinerja mesin dengan menggunakan bahan bakar pertalite.

Semua campuran bahan bakar pertalitebioetanol biji Sorghum diuji dengan berbagai kondisi putaran mesin, yaitu mesin bensin dioperasikan menggunakan bahan bakar pertalite sampai mencapai kondisi stabil. Putaran mesin dan torsi diukur, sementara daya rem, konsumsi bahan bakar spesifik rem, dan efisiensi volumetrik dihitung. Setelah mesin bensin mencapai kondisi kerja yang stabil, emisi gas buang dianalisis dengan menggunakan analisis gas BOSCH. Semua percobaan akan dilakukan pada kondisi beban penuh. Sebelum mendapatkan data dari mesin bensin yang dioperasikan dengan campuran pertalite-bioetanol biji Sorghum baru, mesin dioperasikan dengan menggunakan pertalite selama waktu yang cukup untuk membersihkan sisa bahan bakar dari campuran bahan bakar pertalite-bioetanol biji Sorghum sebelumnya.

\section{HASIL DAN PEMBAHASAN Parameter Kinerja Mesin}

Gambar 2 menunjukkan torsi mesin bahan bakar pertalite dan campuran pertalitebioetanol untuk berbagai variasi putaran mesin. Untuk kedua bahan bakar tersebut, torsi mesin meningkat dengan meningkatnya putaran mesin. Pada 3500 rpm, torsi mesin untuk semua campuran bahan bakar pertalite-bioetanol biji Sorghum meningkat masing-masing sebesar 38,58 Nm (E10), 38,82 Nm (E15), dan 38,95 Nm (E20) dibandingkan dengan menggunakan 
bahan bakar pertalite $(38,27 \mathrm{Nm})$. Ini terjadi karena campuran pertalite-bioetanol biji Sorghum yang diperkaya dengan kandungan oksigen sekitar 5\%-10\% dan memiliki angka oktan lebih tinggi daripada pertalite, sehingga meningkatkan pembakaran. Meskipun penambahan etanol ke pertalite menurunkan nilai kalornya, tetapi peningkatan torsi dan tenaga mesin meningkat. Menurut, Karaaslan $d k k$. (2011) ini terjadi karena beberapa alasan seperti efek etanol sebagai bahan bakar teroksigenasi yang memungkinkan hasil pembakaran bahan bakar yang lebih baik, sehingga meningkatkan torsi. Selain itu, peningkatan konsentrasi bioetanol dalam campuran bahan bakar meningkatkan torsi mesin karena peningkatan viskositas dan densitas. Ini sesuai dengan hasil Najafi $d k k$., (2009), yang melaporkan bahwa kelebihan oksigen dalam etanol meningkatkan rasio udara-bahan bakar dan kepadatan bahan bakar. Di samping itu, menurut Masum $d k k$. (2014) penambahan etanol yang memiliki oksigen menghasilkan campuran bahan bakar yang baik sehingga pembakaran lebih efisien daripada bensin.

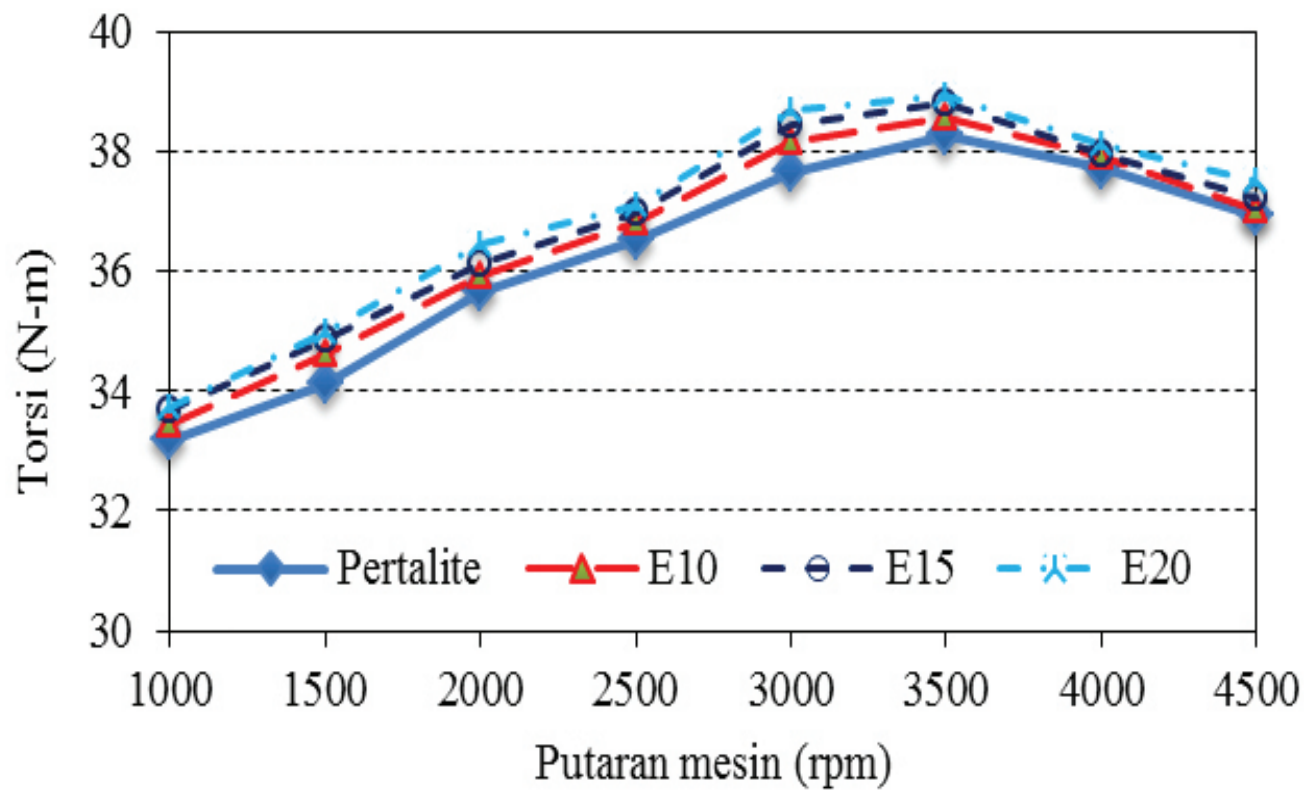

Gambar 2

Pengaruh Campuran Pertalite-Bioetanol Biji Sorghum dan Bahan Bakar Pertalite pada Torsi Mesin Sumber: Analisis Data (2018)

\section{Konsumsi Bahan Bakar Spesifik (BSFC)}

Gambar 3 menunjukkan BSFC untuk pertalite dan campuran pertalite-bioetanol biji Sorghum pada berbagai variasi putaran mesin. BSFC yang terjadi pada $3500 \mathrm{rpm}$, dengan nilai 268,03 g/kWh (E10), 256,65 g/kWh (E15), dan $246,93 \mathrm{~g} / \mathrm{kWh}$ (E20), hasil ini lebih rendah dibandingkan dengan menggunakan bahan bakar pertalite yaitu 279,97 g/kWh. Telah diketahui bahwa nilai BSFC suatu mesin tergantung dari pada nilai kalor bahan bakar. Ketika mesin digunakan tanpa modifikasi, maka kandungan energi yang lebih rendah dari bahan bakar pertalite-bioetanol menyebabkan peningkatan BSFC. Peningkatan tersebut terutama tergantung pada persentase bioetanol. Hasil eksperimen menunjukkan nilai kalor bioetanol sekitar 38\% lebih rendah dari nilai pertalite, sehingga nilai kalor bahan bakar campuran juga turun dibandingkan dengan pertalite. Hal ini mengakibatkan BSFC meningkat dan ini sesuai dengan hasil penelitan dari Koç $d k k$. (2009).

Selain itu, kandungan oksigen yang lebih tinggi dari bioetanol biji Sorghum juga 
memiliki pengaruh yang signifikan terhadap penurunan BSFC. Ketika mesin dioperasikan menggunakan campuran pertalite-bioetanol biji Sorghum, tren BSFC lebih rendah daripada pertalite karena tidak ada modifikasi yang dilakukan pada mesin bensin yang digunakan dalam penelitian ini, kinerja mesin yang diinginkan dikaitkan dengan angka oktan tinggi dari bioetanol, yang menghasilkan pembakaran yang lebih baik dari pada ketika menggunakan pertalite. Hasil pengamatan menunjukkan bahwa BSFC untuk semua bahan bakar campuran bioetanol (E5, E10 dan
E20) lebih rendah daripada pertalite. Tingginya kandungan oksigen menyebabkan peningkatan efisiensi pembakaran dan ini menurunkan BSFC. Hasil ini sesuai dengan kesimpulan dari penelitian Najafi $d k k$. (2009) yang menyatakan bahwa dengan meningkatnya persentasi campuran bioetanol diikuti dengan menurunnya konsumsi bahan bakar spesifik (BSFC). Selain itu, Eyidogan $d k k$. (2010) juga mengatakan pada hasil penelitiannya bahwa pengaruh tingginya kandungan oksigen pada bahan bakar menyebabkan terjadinya penurunan BSFC.

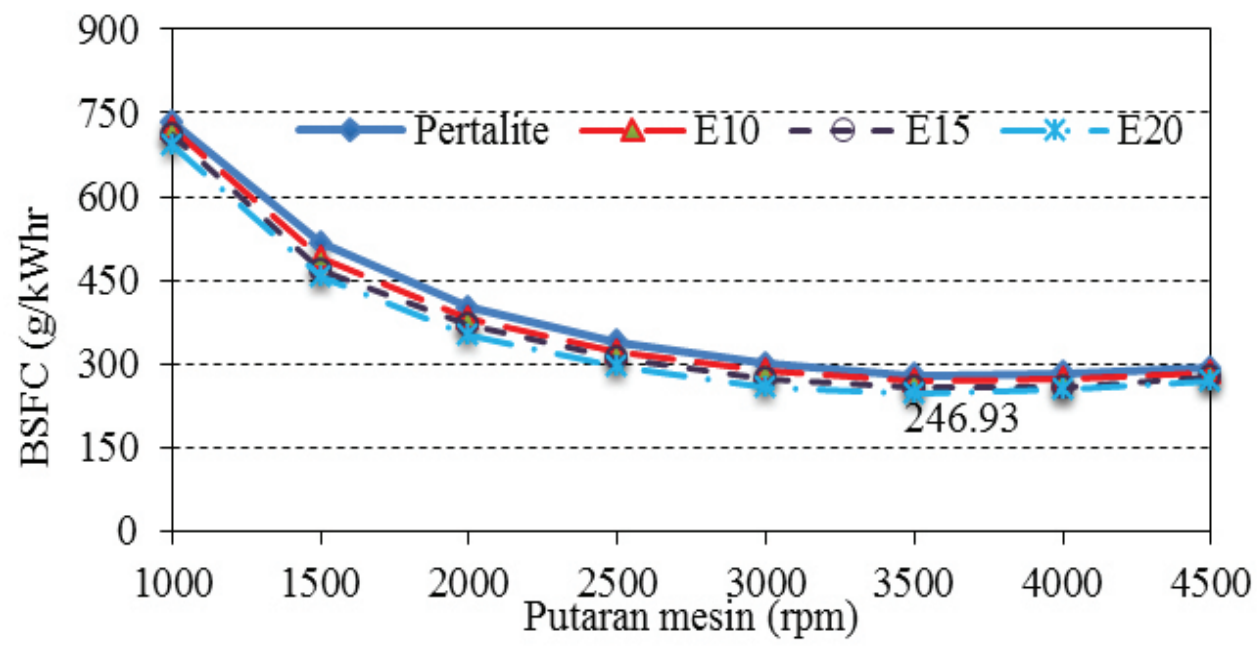

Gambar 3

Pengaruh Campuran Pertalite-Bioetanol Biji Sorghum dan Bahan Bakar Pertalite pada BSFC Sumber: Analisis Data (2018)

\section{Efisiensi Termal Rem (BTE)}

Gambar 4 menunjukkan efisiensi termal rem (BTE) untuk bahan bakar pertalite dan campuran bahan bakar pertalite-bioetanol biji Sorghum pada berbagai variasi putaran mesin. BTE maksimum untuk campuran pertalite-bioetanol biji Sorghum adalah 32,36\% (E10), 34,33\% (E15), dan 36,28\% (E20). BTE maksimum untuk pertalite adalah 29,13\%. BTE meningkat dengan meningkatnya konsentrasi bioetanol dalam campuran bahan bakar, dan ini sesuai dengan hasil (Najafi dkk.,2009). Dari hasil penelitian ini diketahui bahwa BTE untuk campuran pertalite-bioetanol biji Sorghum adalah 16\% lebih tinggi dari pertalite. Hal ini dikarenakan kandungan oksigen pada bahan bakar campuran lebih tinggi dibandingkan dengan pertalite yang tidak mengandung oksigen (Eyidogan $d k k ., 2010)$. Kandungan oksigen berlebih mengarah ke pembakaran yang mendekati sempurna, dan meningkatkan BTE (Masum $d k k$., 2015; Schifter $d k k$., 2011).

\section{Parameter Emisi Gas Buang Emisi Nitrogen Oksida (NOx)}

Konsentrasi emisi NOx cenderung meningkat dengan peningkatan konsentrasi bioetanol dan putaran mesin untuk semua kondisi pengujian seperti yang ditunjukkan pada gambar 5. Emisi NOx umumnya lebih tinggi untuk campuran pertalite-bioetanol biji Sorghum dari pada pertalite, dengan nilai 187,4 
ABDI H. SEBAYANG, H. IBRAHIM, S. DHARMA, A.S. SILITONGA, B. GINTING, DAN

N. DAMANIK PENGARUH CAMPURAN BAHAN BAKAR PERTALITE-BIOETANOL BIJI ...

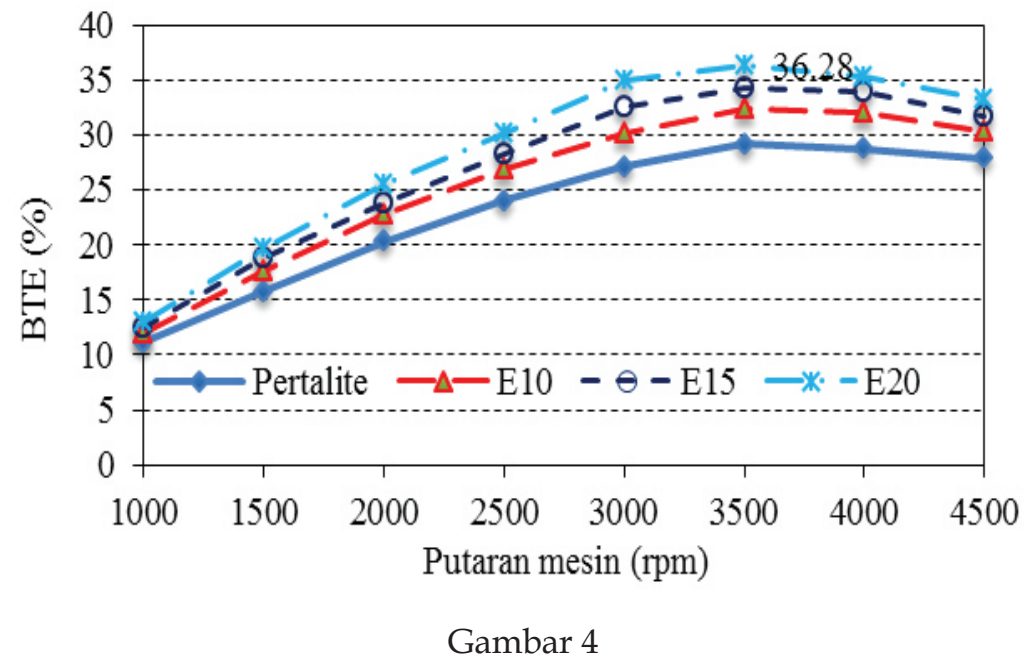

Pengaruh Campuran Pertalite-Bioetanol Biji Sorghum dan Bahan Bakar Pertalite Pada BTE Sumber: Analisis Data (2018)

ppm (E10), 202,6 ppm (E15), dan 218,6 ppm (E20) pada putaran $3500 \mathrm{rpm}$. Sebaliknya, nilai pertalite adalah $174,2 \mathrm{ppm}$. NOx terbentuk pada suhu tinggi dan suhu nyala adiabatik terjadi ketika pembakaran mendekati stoikiometri. Temperatur silinder yang lebih tinggi pada $3.500 \mathrm{rpm}$ menyebabkan peningkatan emisi NOx.

Secara umum, emisi NOx bergantung pada rasio udara-bahan bakar dan suhu. Suhu tinggi selama pembakaran dan kandungan oksigen tinggi dari bioetanol menghasilkan emisi NOx yang tinggi (Celik, 2008). Selain itu, emisi NOx dapat berubah tergantung pada persentase etanol dalam campuran dan kondisi operasi. Suhu tinggi dan oksigen tinggi dapat meningkatkan jumlah kandungan nitrogen bahan bakar (Masum $d k k$., 2013). Oleh karena itu, ini dapat menyebabkan emisi NOx meningkat karena pembakaran menuju yang lebih baik dan menghasilkan suhu pembakaran yang lebih tinggi sehingga memungkinkan lebih banyak NOx diproduksi

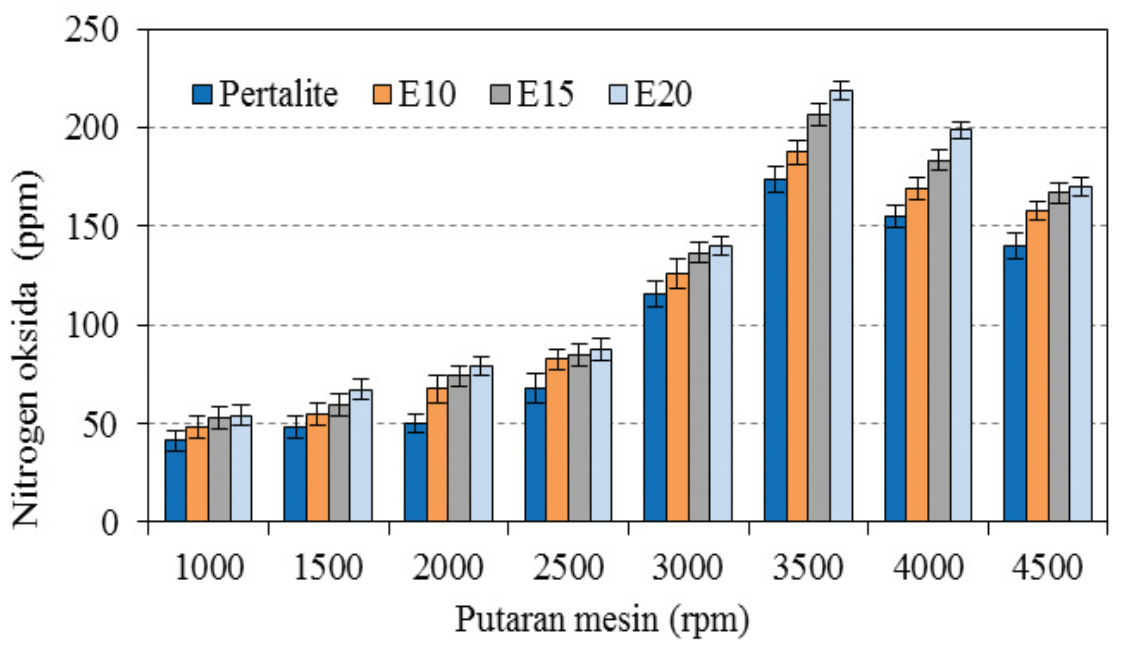

Gambar 5.

Pengaruh Pertalite dan bahan bakar E10-E20 pada emisi $\mathrm{NO}_{x}$ Sumber: Analisis Data (2018) 


\section{Emisi Karbon Monoksida (CO)}

Gas karbon monoksida (CO) adalah gas yang relatif tidak stabil dan cenderung bereaksi dengan elemen lain. Gambar 6 menunjukkan emisi CO untuk campuran pertalite-bioetanol dan pertalite pada berbagai putaran mesin. Emisi CO lebih rendah untuk campuran pertalite-bioetanol daripada untuk pertalite. Selain itu, emisi CO juga menurun rata-rata sebesar 17\% ketika menggunakan bahan bakar campuran pertalite-bioetanol dibandingkan dengan menggunakan bahan bakar pertalite. Emisi CO menurun karena konsentrasi bioetanol dalam campuran bahan bakar meningkat. Emisi CO juga berkurang ketika beban engine meningkat karena meningkatnya rasio udara-bahan bakar dan menghasilkan pembakaran yang lebih baik (Canakci $d k k$., 2013; Ozsezen dan Canakci, 2011). Menurut Costa \& Sodré (2010) dan Ghazikhani $d k k$.
(2013), bioetanol memiliki kandungan oksigen yang tinggi, sehingga oksigen berkontribusi untuk pembakaran campuran udara-bahan bakar yang lebih baik. Di samping itu, pada dasarnya etanol mengandung atom oksigen, sehingga dapat diperlakukan sebagai hidrokarbon teroksidasi sebagian. Ketika etanol ditambahkan ke bahan bakar campuran, ini memberikan lebih banyak oksigen pada proses pembakaran. Ini menunjukkan bahwa mesin cenderung beroperasi dalam kondisi yang lebih ramping, lebih dekat dengan pembakaran stoikiometrik karena kandungan etanol meningkat. Selain itu, suhu gas silinder tinggi dikombinasikan dengan konsentrasi oksigen dari campuran pertalite-bioetanol biji Sorghum meningkatkan proses oksidasi $\mathrm{CO}$, yang menyebabkan penurunan emisi $\mathrm{CO}$ (Alptekin $d k k ., 2015)$.

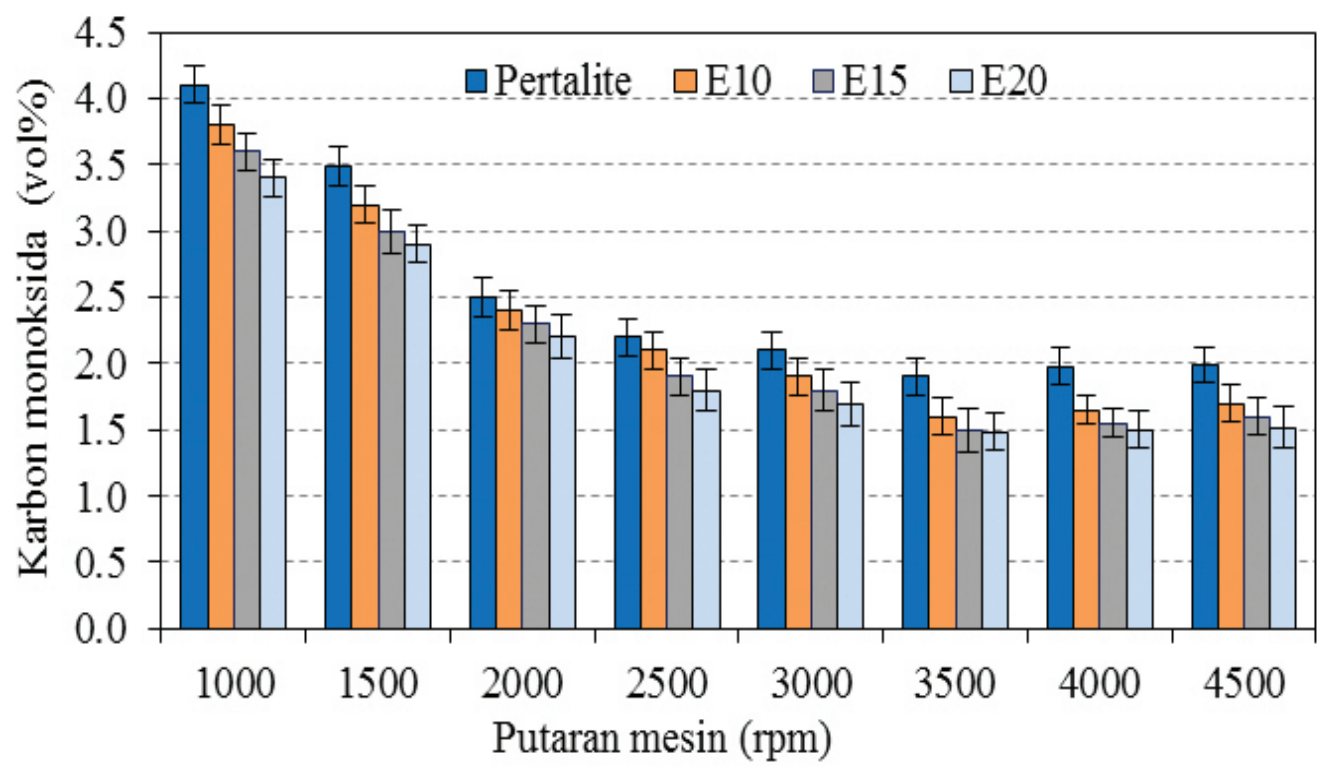

Gambar 6.

Pengaruh Pertalite dan bahan bakar E10-E20 pada emisi CO

Sumber: Analisis Data (2018)

\section{Emisi Hidrokarbon (HC)}

Gambar 7 menunjukkan emisi HC untuk campuran pertalite-bioetanol dan pertalite pada berbagai putaran mesin. Emisi HC turun untuk campuran pertalite-bioetanol dibandingkan dengan pertalite. Seperti yang terlihat dari gambar, $\mathrm{HC}$ terendah yang dihasilkan adalah
40,3 ppm (E20) pada 3500 rpm. Namun, HC terendah yang diproduksi oleh pertalite adalah 49,7 ppm pada $3500 \mathrm{rpm}$. Konsentrasi bioetanol memiliki efek yang signifikan terhadap penurunan emisi HC. Menurut Schifter $d k k$. (2011) meningkatnya kandungan etanol dalam bahan bakar campuran menghasilkan 
ABDI H. SEBAYANG, H. IBRAHIM, S. DHARMA, A.S. SILITONGA, B. GINTING, DAN N. DAMANIK \& PENGARUH CAMPURAN BAHAN BAKAR PERTALITE-BIOETANOL BIJI ...

penurunan HC. Emisi HC turun rata-rata sebesar $8 \%$, ketika menggunakan bahan bakar campuran pertalite-bioetanol dibandingkan dengan menggunakan bahan bakar pertalite. Emisi HC lebih tinggi pada putaran engine yang lebih rendah (1000 rpm) karena kalor penguapan yang tinggi dari bioetanol, yang mengakibatkan penguapan lambat dan pencampuran udara-bahan bakar yang buruk. Ketika putaran mesin dinaikkan, campuran udara bahan bakar menjadi lebih homogen dan mesin bergerak menuju pembakaran stoikiometri, karenanya meningkatkan suhu nyala adiabatik dan menghasilkan pembakaran yang lebih baik sehingga emisi HC menurun karena kandungan bioetanol meningkat (Chansauria dan Mandloi, 2018; Saikrishnan $d k k$., 2018). Di samping itu, karakteristik pengkabutan bahan bakar sangat dipengaruhi oleh sifat aliran di dalam pengkabutan bahan bakar dan udara di ruang bakar, yang berperan dalam mengurangi emisi HC yang tidak terbakar (Alptekin dkk., 2015).

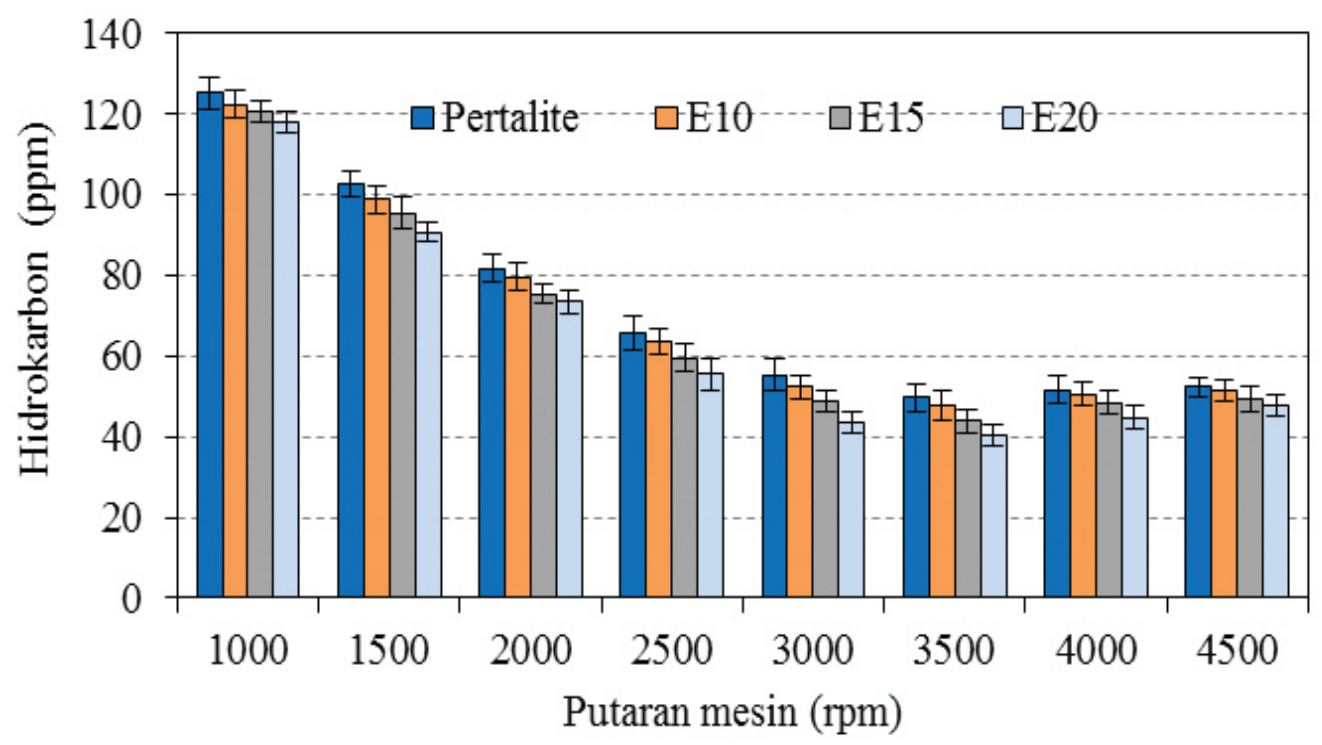

Gambar 7.

Pengaruh Pertalite dan bahan bakar E10-E20 pada emisi HC

Sumber: Analisis Data (2018)

\section{SIMPULAN}

Bahan bakar alternatif menjadi semakin penting disektor otomotif karena menipisnya cadangan bahan bakar fosil serta masalah lingkungan yang dihasilkan dari pembakaran bahan bakar fosil. Bioetanol dianggap sebagai bahan bakar alternatif ramah lingkungan, bersih, dan terbarukan untuk mesin bensin. Penggunaan bahan bakar campuran pertalitebioetanol biji Sorghum menghasilkan sedikit peningkatan pada torsi mesin, daya rem, dan BTE namun menurunkan BSFC. Di sisi lain, emisi CO dan HC menurun karena efek dari etanol pada campuran pertalite-bioetanol dibandingkan dengan pertalite. Emisi NOx meningkat untukcampuraninikarena tingginya panas laten vaporisasi dan kandungan oksigen dari bahan bakar, bersama dengan suhu pembakaran yang tinggi. Secara umum, ada peningkatan kinerja mesin dan penurunan emisi gas buang untuk bahan bakar campuran (E20), yang mengandung 20\% bioetanol yang dicampur dengan pertalite. Dengan demikian, campuran E20 tampaknya menjadi pengganti yang baik untuk bahan bakar dari minyak bumi fosil guna meningkatkan kinerja mesin dan penurunan emisi gas buang.

\section{Ucapan Terima kasih}

Para penulis dengan penuh rasa syukur menyampaikan penghargaan dan mengucapkan terima kasih atas dukungan 
finansial yang diberikan oleh Kementerian Riset, Teknologi, dan Pendidikan Tinggi melalui dana DIPA Politeknik Negeri Medan Tahun 2018.

\section{DAFTAR PUSTAKA}

Aditiya, H.B., Mahlia, T.M.I., Chong, W., Nur, H., dan Sebayang, A.H. 2016. Second Generation Bioethanol Production: A Critical Review. Renewable and Sustainable Energy Reviews, 66: 631653.

Alptekin, E., Canakci, M., Ozsezen, A.N., Turkcan, A., dan Sanli, H. 2015. Using Waste Animal Fat Based Biodiesels-Bioethanol-Diesel Fuel Blends in a DI Diesel Engine. Fuel, 157: 245-254.

Barcelos, C., Maeda, R., Betancur, G., dan Pereira Jr, N. 2011. Ethanol Production from Sorghum Grains [Sorghum Bicolor (L.) Moench]: Evaluation of the Enzymatic Hydrolysis and the Hydrolysate Fermentability. Brazilian Journal of Chemical Engineering, 28: 597-604.

Canakci, M., Ozsezen, A.N., Alptekin, E., dan Eyidogan, M. 2013. Impact of Alcohol-Gasoline Fuel Blends on the Exhaust Emission of an SI Engine. Renewable Energy, 52: 111-117.

Çay, Y., Korkmaz, I., Çiçek, A., dan Kara, F. 2013. Prediction of Engine Performance and Exhaust Emissions for Gasoline and Methanol using Artificial Neural Network. Energy, 50: $177-186$.

Celik, M.B. 2008. Experimental Determination of Suitable Ethanol-Gasoline Blend Rate at High Compression Ratio for Gasoline Engine. Applied Thermal Engineering, 28: 396-404.

Chansauria, P., dan Mandloi, R. 2018. Effects of Ethanol Blends on Performance of Spark Ignition Engine-a Review. Materials Today: Proceedings, 5: 40664077.
Costa, R.C., dan Sodré, J.R. 2010. Hydrous Ethanol Vs. Gasoline-Ethanol Blend: Engine Performance and Emissions. Fuel, 89: 287-293.

Deesuth, O., Laopaiboon, P., Klanrit, P., dan Laopaiboon, L. 2015. Improvement of Ethanol Production from Sweet Sorghum Juice Under High Gravity and Very High Gravity Conditions: Effects of Nutrient Supplementation and Aeration. Industrial Crops and Products, 74: 95-102.

Elhassan, M.S., Emmambux, M.N., Hays, D.B., Peterson, G.C., dan Taylor, J.R. 2015. Novel Biofortified Sorghum Lines with Combined Waxy (High Amylopectin) Starch and High Protein Digestibility Traits: Effects on Endosperm and Flour Properties. Journal of Cereal Science, 65: 132-139.

Eyidogan, M., Ozsezen, A.N., Canakci, M., dan Turkcan, A. 2010. Impact of Alcohol-Gasoline Fuel Blends on the Performance and Combustion Characteristics of an SI Engine. Fuel, 89: 2713-2720.

Ghazikhani, M., Hatami, M., Safari, B., dan Ganji, D.D. 2013. Experimental Investigation of Performance Improving and Emissions Reducing in a Two Stroke SI Engine by using Ethanol Additives. Propulsion and Power Research, 2: 276-283.

Houx III, J.H., dan Fritschi, F.B. 2015. Influence of Late Planting on Light Interception, Radiation use Efficiency and Biomass Production of Four Sweet Sorghum Cultivars. Industrial Crops and Products, 76: 6268.

Ibrahim, H., Sebayang, A.H., Dharma, S., dan Silitonga, A.S. 2017. Prediksi Kinerja Mesin Diesel dengan Bahan Bakar Biodiesel-Solar menggunakan Artificial Neural Network. Jurnal Muara Sains, Teknologi, Kedokteran dan Ilmu Kesehatan, 1. 
ABDI H. SEBAYANG, H. IBRAHIM, S. DHARMA, A.S. SILITONGA, B. GINTING, DAN

N. DAMANIK * PENGARUH CAMPURAN BAHAN BAKAR PERTALITE-BIOETANOL BIJI ...

Karaaslan, S., Erman, C., Hepkaya, E., dan Yücel, N. 2011. Numerical Investigation of Ethanol Fuel Blends on Engine Performance Characteristics by using DieselRK Software. International Scientific Journal: 36-39.

Koç, M., Sekmen, Y., Topgül, T., dan Yücesu, H.S. 2009. The Effects of EthanolUnleaded Gasoline Blends on Engine Performance and Exhaust Emissions in a Spark-Ignition Engine. Renewable Energy, 34: 2101-2106.

Marx, S., Ndaba, B., Chiyanzu,I., danSchabort, C. 2014. Fuel Ethanol Production From Sweet Sorghum Bagasse using Microwave Irradiation. Biomass and Bioenergy, 65: 145-150.

Masum, B., Kalam, M., Masjuki, H., Palash, S., dan Fattah, I.R. 2014. Performance and Emission Analysis of a Multi Cylinder Gasoline Engine Operating at Different Alcohol-Gasoline Blends. RSC Advances, 4: 2789827904.

Masum, B., Masjuki, H., Kalam, M., Fattah, I.R., Palash, S., dan Abedin, M. 2013. Effect of Ethanol-Gasoline Blend on Nox Emission in SI Engine. Renewable and Sustainable Energy Reviews, 24: 209-222.

Masum, B., Masjuki, H.H., Kalam, M.A., Palash, S., dan Habibullah, M. 2015. Effect of Alcohol-Gasoline Blends Optimization on Fuel Properties, Performance and Emissions of a SI Engine. Journal of Cleaner Production, 86: 230-237.

Mehboob, S., Ali, T.M., Alam, F., dan Hasnain, A. 2015. Dual Modification of Native White Sorghum (Sorghum Bicolor) Starch via Acid Hydrolysis and Succinylation. LWT-Food Science and Technology, 64: 459-467.

Miller, G.L. 1959. Use of Dinitrosalicylic Acid Reagent for Determination of
Reducing Sugar. Analytical Chemistry, 31: 426-428.

Najafi, G., Ghobadian, B., Tavakoli, T., Buttsworth, D., Yusaf, T., dan Faizollahnejad, M. 2009. Performance and Exhaust Emissions of a Gasoline Engine With Ethanol Blended Gasoline Fuels Using Artificial Neural Network. Applied Energy, 86: 630-639.

Ozsezen, A.N., dan Canakci, M. 2011. Performance and Combustion Characteristics of Alcohol-Gasoline Blends at Wide-Open Throttle. Energy, 36: 2747-2752.

Pengilly, C., García-Aparicio, M., Diedericks, D., Brienzo, M., dan Görgens, J. 2015. Enzymatic Hydrolysis of SteamPretreated Sweet Sorghum Bagasse by Combinations of Cellulase and Endo-Xylanase. Fuel, 154: 352-360.

Saikrishnan, V., Karthikeyan, A., dan Jayaprabakar, J. 2018. Analysis of Ethanol Blends on Spark Ignition Engines. International Journal of Ambient Energy, 39: 103-107.

Schifter, I., Diaz, L., Rodriguez, R., Gómez, J., dan Gonzalez, U. 2011. Combustion and Emissions Behavior for EthanolGasoline Blends in a Single Cylinder Engine. Fuel, 90: 3586-3592.

Sebayang, A.H., Masjuki, H., Ong, H.C., Dharma, S., Silitonga, A.S., Kusumo, F., dan Milano, J. 2017a. Optimization of Bioethanol Production from Sorghum Grains using Artificial Neural Networks Integrated with Ant Colony. Industrial Crops and Products, 97: 146-155.

Sebayang, A.H., Masjuki, H., Ong, H.C., Dharma, S., Silitonga, A.S., Kusumo, F., dan Milano, J. 2017b. Prediction of Engine Performance and Emissions with Manihot Glaziovii BioethanolGasoline Blended using Extreme Learning Machine. Fuel, 210: 914-921. 
Sebayang, A.H., Masjuki, H., Ong, H.C., Dharma, S., Silitonga, A.S., Mahlia, T.M.I., dan Aditiya, H.B. 2016. A perspective on BioethanolProduction from Biomass as Alternative Fuel for Spark Ignition Engine. RSC Advances, 6: 14964-14992.

Teoh, Y., Masjuki, H.H., Kalam, M., dan How, H. 2015. Comparative Assessment of Performance, Emissions and Combustion Characteristics of Gasoline/Diesel and Gasoline/ Biodiesel in a Dual-Fuel Engine. RSC Advances, 5: 71608-71619.
Widianto, D., Pramita, A.D., dan Wedhastri, S. 2013. Perbaikan Proses Fermentasi Biji Kakao Kering dengan Penambahan Tetes Tebu, Khamir, dan Bakteri Asam Asetat. Jurnal Teknosains, 3(1):38-44.

Yücesu, H.S., Topgül, T., Cinar, C., dan Okur, M. 2006. Effect of Ethanol-Gasoline Blends on Engine Performance and Exhaust Emissions in Different Compression Ratios. Applied Thermal Engineering, 26: 2272-2278.

Zhang, C., Xie, G., Li, S., Ge, L., dan He, T. 2010. The Productive Potentials of Sweet Sorghum Ethanol in China. Applied Energy, 87: 2360-2368. 